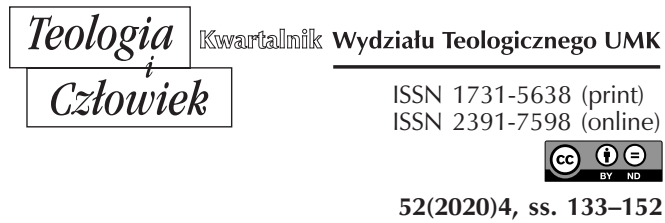

MICHAŁ MIKOŁAJCZAK

\title{
KSIĄŻĘ APOSTOŁÓW - SŁUGA SŁUG BOŻYCH O OCZYSZCZANIU PAPIESKIEJ LITURGII ZE ŚWIECKIEGO PROTOKOŁU
}

DOI: http://dx.doi.org/10.12775/TiCz.2020.055

Gdyż on rzymskiemu państwu i Rzymowi $\mathrm{Na}$ patryjarchę był naznaczon $\mathrm{z}$ wieka. (Dante Alighieri, Boska Komedia)

Streszczenie. Artykuł stanowi próbę opracowania dawnych zwyczajów i tradycji towarzyszących liturgii papieskiej. Poprzez podjętą analizę dokumentów i opracowań zostały zostały zależności, jakie zachodzą między liturgią Kościoła Katolickiego a ceremoniałem dyplomatycznym.

Podążając za wskazówkami abp. Piero Mariniego (Mistrza Papieskich Ceremonii Liturgicznych w latach 1987-2007) zawartymi w książce Liturgia i piękno. Nobilis pulchritudo, autor ukazał przeplatanie się liturgii i świeckiego protokołu na trzech płaszczyznach. Omówione zostało użycie trąb podczas uroczystości z udziałem Ojca Świętego, a także papieskie paramenta oraz papieski orszak. Zawarte w opracowaniu spostrzeżenia mogą stanowić punkt wyjścia do dalszej analizy tematu. Zależności pomiędzy sprawowanym kultem a sprawowaniem władzy mają swoje historyczne uzasadnienie. Tak jak w liturgii odkrywamy świecki protokól, tak w protokole dostrzegamy elementy liturgii. 
Słowa kluczowe: liturgia; liturgia papieska; papiestwo; papież; monarcha; protokół dyplomatyczny; ceremoniał; etykieta; trąby; pochód; procesja; orszak; falda; subcintorium; fanon; mantum; tiara.

Abstract. The Prince of the Apostles - Servant of the Servants of God. On Purifying the Papal Liturgy from Secular Protocol. The article is an attempt to elaborate on old customs and traditions accompanying the papal liturgy. The analysis of documents and studies reveals the relationships between the liturgy of the Catholic Church and the diplomatic ceremony.

Following the instructions of Archbishop Piero Marini (Master of Pontifical Liturgical Celebrations in 1987-2007) included in the book Liturgy and Beauty. Nobilis Pulchritudo, the author of the article shows the interweaving of liturgy and secular protocol on three levels. The use of trumpets during ceremonies with the Holy Father, as well as the papal paraments and the papal procession was discussed. The observations made in the study may serve as a starting point for further analysis of the topic as the relationships between cult, and exercising power have their historical justification. Just as in the liturgy we discover the secular protocol, so in the protocol we observe the elements of the liturgy.

Keywords: liturgy; papal liturgy; papacy; pope; monarch; diplomatic protocol; ceremonial; etiquette; trumpets; parade; procession; cortege; falda; subcintorium; fanon; mantum; tiara.

\section{PAPIEŻ - BISKUP I MONARCHA}

Liturgia semper reformanda est - powtarzana od wieków zasada, ukazuje liturgię Kościoła katolickiego jako rzeczywistość żywą, dynamiczną i podlegającą zmianom. Podejmując refleksję nad publicznym kultem Kościoła, dostrzegamy, że dzisiejsza liturgia różni się od tej z czasów apostolskich. Różni się także od tej sprawowanej po reskrypcie mediolańskim (do IV w.), następnie od liturgii z czasów karolińskich (VI-XI w.), po reformie Grzegorza (XI w.), a także tej najbardziej rozbudowanej i skodyfikowanej, po Soborze Trydenckim (1545-1563) ${ }^{1}$. Jej rozwojowi towarzyszył szereg zarówno pozytywnych, jak i negatywnych zmian. Do tych pozytywnych, z pewnością zaliczymy te mające na celu przysposo-

1 Zob. B. Nadolski, Liturgika, t. I: Liturgika fundamentalna, Poznań 1989, s. $29-56$. 
bienie liturgicznego skarbca dla wiernych wszystkich miejsc i czasów. Zaznaczyć należy, że owe przysposobienie nie jest tzw. pójściem z duchem czasu, lecz ciągłym swoistym katharsis liturgii, której centrum stanowi kult sprawowany wobec Boga w Trójcy Świętej Jedynego. Analizując historię liturgii, dostrzeżemy również zmiany niekorzystne, które jednak w danym czasie $\mathrm{z}$ różnych potrzeb i względów w publicznym kulcie znalazły swoje miejsce. Z perspektywy czasu jawią się one jako różnego rodzaju „dodatki” wynikające z „nadpobożności”, zbytniej świeckości czy „twórczości” danej wspólnoty lokalnej. Ciekawym aspektem, na który warto zwrócić uwagę, a któremu poświęcone będzie niniejsze przedłożenie, jest wspólna zależność zachodząca między liturgią Kościoła a protokołem, ceremoniałem i etykietą dyplomatyczną. Liturgia Kościoła powstała w konkretnym miejscu i czasie ${ }^{2}$. Kształtowała się i nadal kształtuje wśród konkretnych wspólnot. Dlatego oczywiste jest, że w liturgicznym akcie Kościoła dostrzeżemy świeckie tradycje i zwyczaje. Możemy przyjąć, że do IV wieku Kościół czerpał z liturgii żydowskiej oraz z zasad, jakie panowały na cesarskich dworach, a także ze spuścizny starożytnej Grecji. Antyczna kultura rzymska i grecka zawierały natomiast wchłonięte wcześniej kultury wschodu oraz podbitych ludów. W późniejszych wiekach, zachowując oraz rozwijając to, co zostało wypracowane, stał się zarówno strażnikiem, jak i kreatorem szeroko pojmowanej dyplomacji.

Poszukując związków liturgii Kościoła z ceremoniałem świeckim, oczywista jest analiza liturgii papieskiej - sprawowanej przez Biskupa Rzymu, głowę państwa ${ }^{3}$. Nadmienić należy, że badania nad liturgią poszczególnych stolic biskupich również przyniosłyby wiele ciekawych informacji i spostrzeżeń, jednakże to właśnie: „W liturgii Pałacu Apostolskiego zachowywane były niczym w drogocennym skarbcu zwyczaje i tradycje wszędzie indziej porzucone lub zapomniane, które związane

2 Zob. J. Janicki, Kultury antyczne w liturgii chrześcijańskiej, Kraków 2007.

3 Zob. H. Suchocka, W 75 rocznicę podpisania Traktatów Laterańskich. Refleksje na temat relacji Stolica Apostolska a Państwo - Miasto Watykan, w: A. Dębiński, K. Orzeszyna, M. Sitarz (red.), Ecclesia et Status, Księga jubileuszowa z okazji 40-lecia pracy naukowej ks. profesora Józefa Krukowskiego, Lublin 2004. oraz T. Olejarz, Podmiotowość Stolicy Apostolskiej w prawie międzynarodowym, „Annales Universitatis Mariae Curie-Skłodowska” 16 (2009) 1, s. 65-94. 
były przede wszystkim z czcią, jaką otaczana jest droga dla chrześcijan osoba Namiestnika Chrystusowego ${ }^{4}$ ".

Liturgia papieska, zwana również apostolską, a w licznych dokumentach i publikacjach określana terminem „kaplicy papieskiej” jest liturgią wzorcową dla całego chrześcijańskiego (katolickiego) świata. Co kryje za sobą sformułowanie „kaplica papieska”? XIX-wieczny włoski erudyta, autor licznych opracowań, Gaetano Moroni, zanotował:

Nazywamy kaplicami papieskimi Nieszpory, modlitwy poranne, Msze śpiewane i inne kościelne ceremonie, w jakich udział bierze Najwyższy Pasterz lub jakie on sam sprawuje według czcigodnych rytów Kościoła rzymskiego w obecności kardynałów, patriarchów, arcybiskupów i prałatów jak i wielkiej liczby generałów zakonów religijnych oraz pierwszych dygnitarzy Dworu Papieskiego i Rodziny papieskiej ${ }^{5}$.

Oczywiście najczcigodniejszym, a więc i najbardziej rozbudowanym aktem liturgicznym jest Msza święta, zatem w sposób szczególny skupimy się na tym wszystkim, co się z nią łączy. Warto przytoczyć fragment Ordines przygotowanych na koronację Jana XXII, a użytych również podczas koronacji Pawła VI:

Jako że Msza święta jest najdostojniejszym ze wszystkich aktów liturgicznych, Kościół zawsze otaczał jej uroczystą celebrację największym możliwym splendorem. W szczególności Msza pontyfikalna biskupa niesie z sobą bogaty ceremoniał przeznaczony do tego, by uwypuklić godność tego, który celebruje. Naturalnym jest, że Msza solenna Najwyższego Pasterza przekracza swą wspaniałością ten wspomniany. Nie mówiąc o tym, jak istotna jest obecność zgromadzenia dygnitarzy kościelnych jak i świeckich, którzy uwypuklają ten blask, liturgia ta zachowała w całości ryty dziś nieobecne we wszystkich innych ceremoniach Kościoła ${ }^{6}$.

Obecność protokołu dyplomatycznego w liturgii, już po krótkiej obserwacji staje się bardzo mocno widoczna. Tę samą zależność dostrzeże-

${ }^{4}$ B. Krzych, Historia, źródła i ceremonie solennej Mszy papieskiej według usus antiquior, „Christianitas” 52 (2013), s. 178-179.

5 Tamże, s. 180.

6 Tamże, s. 193. 
my w protokole dyplomatycznym zawierającym elementy liturgii, a nawet, wśród dyplomatów nazywanym „liturgią dyplomacji”" Formułowana często myśl, że czym liturgia w kościele tym ceremoniał na dworze, nie oddaje dobrze tej rzeczywistości. Dwie te płaszczyzny tak mocno współgrają, współistnieją i przenikają się, że taki podział i określenie wzajemnych zależności staje się niemożliwe. Tak bowiem, jak dostrzegamy elementy protokołu, ceremoniału i etykiety w liturgii, tak w nich dostrzeżemy elementy liturgii. Podejmując analizę papieskich celebracji sprzed reform św. Pawła VI, słusznie możemy odnieść wrażenie, że dworski ceremoniał brał górę nad liturgią rozumianą jako uobecnienie wydarzeń zbawczych. Nad tym właśnie aspektem podczas Soboru Watykańskiego II pochylili się Ojcowie Soborowi, którzy w Konstytucji Sacrosanctum Concilium wezwali do oczyszczenia liturgii.

Porządek Mszy należy tak przerobić, aby wyraźniej uwidocznić właściwe znaczenie i wzajemny związek poszczególnych części, a wiernym bardziej ułatwić pobożny i czynny udział. W tym celu obrzędy należy uprościć, zachowując wiernie ich istotę, należy opuścić to, co z biegiem czasu stało się powtórzeniem lub dodatkiem bez większej korzyści. Natomiast pewne elementy, zatracone w ciągu wieków, należy przywrócić stosownie do pierwotnej tradycji Ojców Kościoła, o ile to będzie pożyteczne lub konieczne ${ }^{8}$.

Konstytucja o liturgii stała się początkiem pogłębionej refleksji liturgicznej, a także pragnieniem powrotu do rzymskiej liturgii klasycznej sprawowanej od IV do VI wieku. Abp P. Marini, mistrz papieskich ceremonii w czasie pontyfikatu Jana Pawła II i Benedykta XVI, podejmując rozważania nad liturgiczną odnową, zanotował w książce Liturgia i piękno. Nobilis pulchritudo:

aż do Soboru Watykańskiego II papież podczas wielkich uroczystości wchodził do Bazyliki św. Piotra przy dźwięku trąb. Nosił tiarę, rękawiczki, buty w odpowiednim kolorze dostosowanym do liturgii. Był wnoszony w lekty-

${ }^{7}$ Cyt. za: T. Orłowski, Protokół dyplomatyczny. Między tradycją a nowoczesnościa, https://wszystkoconajwazniejsze.pl/tomasz-orlowski-protokol-dyplomatyczny/ (dostęp: 25.05.2020).

8 Sobór Watykański II, Konstytucja o liturgii świętej „Sacrosanctum Concilium”, Konstytucja soborowa Sacrosantcum Concilium, nr 50. 
ce, pośród wachlarzy z piór i pokaźnej, różnobarwnej grupy osób świeckich i prałatów, ubranych we własny oficjalny strój, oraz przedstawicieli szlachty i rzymskich patrycjuszy, rozmaitych korpusów straży i innych dostojników dworu papieskiego. Chodziło w tym o uroczyste wejście, które nadawało papieżowi wygląd księcia tego świata, otoczony przez własny dwór99.

Oczywiście temat protokołu podczas liturgii papieskiej jest niezwykle szeroki, dlatego w niniejszym przedłożeniu, trzymając się przytoczonych słów papieskiego ceremoniarza, zwrócimy uwagę tylko na 3 aspekty, które w dość mocny sposób charakteryzują liturgię papieską sprzed reform św. Pawła VI: 1) dźwięk trąb, 2) paramenta papieskie, 3) orszak papieski. Refleksja na tych trzech płaszczyznach pozwoli nam choć po części zrekonstruować i zrozumieć dawną liturgię kaplicy papieskiej. W wielu przypadkach trudno jest określić konkretny moment, w jakim dany strój czy zwyczaj wszedł do liturgii. Tak samo trudno jest określić, czy na stałe jego użycie czy praktyka zostały zaniechane. Przykładem może być papieski fanon, który używany był jeszcze na początku pontyfikatu Jana Pawła II, następnie papież z niego zrezygnował. Powrócił natomiast do niego Benedykt XVI, a jego następca Franciszek do tej pory go nie użył. Trąby, choć nie są już obecne podczas każdej liturgii sprawowanej przez papieża, nadal grają, obwieszczając jego wejście podczas największych uroczystości (np. Boże Narodzenie, Wielkanoc, Święto Apostołów Piotra i Pawła etc.). Niewątpliwie jednak liturgia papieska stała się bardziej przejrzysta i czytelniej wskazuje na Tego, który jest w niej najważniejszy, czyli Chrystusa. Odnowiona liturgia nie ma na celu podkreślania potęgi papieża jako głowy państwa, lecz jest realizacją świętego urzędu biskupiego.

\section{TRĄBA GROŹNYM ZABRZMI TONEM WSZYSTKICH STAWI NAS PRZED TRONEM ${ }^{10}$}

Dźwięk trąb kojarzy się nam zarówno z wydarzeniem szczególnej rangi, niezwykle dostojnym i uroczystym, jak również z wzywaniem

9 P. Marini, Liturgia i piękno. Nobilis pulchritudo, Pelplin 2007, s. 76.

10 Sekwencja Dies irae, (tłum. wł.) w: Liber usualis. Missae et officii, Parisiis-Tornaci-Romae 1951 s. 1810-1811. 
do walki, czy sygnałem ostrzegawczym. Podczas wertowania kart Starego Testamentu w kilku fragmentach odnajdziemy informacje o tym instrumencie. Grano na nich przy przeniesieniu Arki Pana: „Kapłani: Szebaniasz, Jozafat, Netaneel, Amasaj, Zachariasz, Benajasz i Eliezer grali na trąbach przed Arką Bożą” (1 Krn 15,24) oraz „...a z nimi stu dwudziestu kapłanów, grających na trąbach” (2 Krn 5,12). Grano na nich również jako zapowiedź walki: „Wtedy zaczęli grać na trąbach i podnieśli ogromny krzyk" (1 Mch 3,54) oraz by zburzyć mury Jerycha (Joz 6,1-21) - „siódmego dnia okrążycie miasto siedmiokrotnie, a kapłani zagrają na trąbach" (Joz 6,4). W licznych fragmentach Starego Testamentu dostrzegamy, że na trąbach grali kapłani - sprawujący w imieniu ludu kult, m.in.: 1) „a kapłani: Eliakim, Maasejasz, Miniamin, Micheasz, Elioenaj, Zachariasz, Chananiasz byli z trąbami” (Ne 12,41); 2) „Wtedy odzywali się synowie Aarona i grali na kutych trąbach, grzmieli donośnym głosem na pamiątkę przed Najwyższym” (Syr 50,16); 3) „A gdy budowniczowie założyli fundamenty świątyni Pańskiej, wtedy wystąpili kapłani w szatach uroczystych, z trąbami” (Ezd 3,10). W Nowym Testamencie trąby występują w Apokalipsie, kiedy zapowiadają zniszczenie świata (Ap 8-9), „A siedmiu aniołów, mających siedem trąb, przygotowało się, aby zatrąbić” (Ap 8,6).

Również źródła poza biblijne mówią nam o tym instrumencie. Przykładem może być starożytny Egipt, gdzie instrumenty dęte stanowiły bardzo ważny element w muzyce. Wśród nich wyróżniano trąbki, które były znakiem wodza i władcy. Potwierdzają to m.in. odkrycia w grobowcu Tutanchamona ${ }^{11}$. Trąbki były znane również w kulturze etruskiej i to właśnie z niej przeszły do kultury starożytnego Rzymu. Wykonywane były najczęściej z baranich i krowich rogów. Używano ich przede wszystkim jako sygnałów ostrzegawczych, czy zwołujących bitwę. Starożytni pisarze opisują wykorzystanie trąb podczas procesji żałobnych i weselnych ${ }^{12}$.

Temat instrumentów dętych w kulturze starożytnej na podstawie „Uczty Trymalchiona” opracował w artykule: Symphonia, simphoniacus u Petroniusza - analiza semantyczna M. Heintze ${ }^{13}$. Jak zauważa, muzycy

11 Zob. H.A. Schlögl, Starożytny Egipt. Historia i kultura od czasów najdawniejszych do Kleopatry, Warszawa 2012, s. 79-82.

12 Zob. J.G. Landels, Muzyka starożytnej Grecji i Rzymu, Kraków 2005, s. 202-206.

13 Zob. M. Heintze, Symphonia, simphoniacus u Petroniusza - analiza semantyczna, w: Symbolae Philologorum Posnaniensium Graecae et Latinae XXIX/1 2019, s. 53-63. 
pełnili bardzo ważną rolę w życiu publicznym oraz podczas prywatnych uczt i rozrywek. Trymalchion, na którym skupia się autor, upodobał sobie w sposób szczególny popisy trębaczy - przez co możemy przypuszczać, że podczas wydawanych przez niego uczt: „prywatna kapela składała się też głównie $z$ instrumentów dętych" ${ }^{14}$. Użycie trąb towarzyszyło również wydarzeniom o charakterze publicznym. Enkolpiusz, naoczny świadek barwnego pochodu Trymalchiona, opisując wydarzenie, notuje, że wśród tłumu niewolników, świadczących o zamożności właściciela, znajdował się muzyk, którego zadaniem było umilać właścicielowi drogę do domu ${ }^{15}$. M. Heintze w swoim przedłożeniu przywołuje również Podręcznik wojskowości rzymskiej Wegecjusza, który wyjaśnia nam sposób i znaczenie użycia dętych instrumentów. „Odgłosy wszystkich instrumentów dętych (tuba, cornu, bucina) w wojsku rzymskim miały określone znaczenie. Tubicen prowadził żołnierzy do walki, a także ogłaszał odwrót wojska z pola bitwy. Cornicines byli odpowiedzialni za kierowanie całymi oddziałami wojskowymi. Wreszcie bucinatores ogłaszali obecność dowódcy”" ${ }^{16}$.

Możemy wnioskować, że jeżeli trąby znane były w starożytnym Rzymie, znane były również na papieskim dworze. W którym momencie zaczęły uświetniać liturgię papieską - nie wiadomo. Dostojny dźwięk instrumentów dętych podkreśla rangę wydarzenia. Ukazuje potęgę władcy. Do dziś stanowi nieodłączną część ceremoniału dyplomatycznego, zarówno na dworach monarszych (np. Wielka Brytania) czy w Pałacach prezydenckich (np. Polska). Jak podkreśla abp. P. Marini, „dźwięk trąb miał nadać niezwykły i niepowtarzalny charakter, podkreślający znaczenie papieża w wymiarze świeckim"17.

\section{OJCIEC KRÓLÓW I KSIĄŻĄT}

Pontyfikalny strój papieża przed wprowadzaniem reform liturgicznych był bardzo bogaty ${ }^{18}$. Do stroju papieża jako biskupa, czyli mającego

14 Tamże, s. 62.

15 Tamże, s. 54.

16 Tamże, s. 61.

17 Zob. P. Marini, Liturgia i piękno. Nobilis pulchritudo, s. 74-77.

18 Zob. M. Kępczyński, Strój liturgiczny i pozaliturgiczny w papieskiej praxis Bene- 
pełnię święceń dochodziły te części ubioru, które wyróżniały go na tle episkopatu oraz ukazywały, że jest on pierwszy, najważniejszy, że to on prowadzi i, że to jemu powierzone są klucze Królestwa Niebieskiego. Ubierając się przed liturgią ${ }^{19}$, papież zakładał humerał oraz albę i przewiązywał się cingulum. Następnie ze względu na święcenia niższe, przywdziewał tunicelę (subdiakonat) i dalmatykę (diakonat). Jako kapłan zakładał ornat i manipularz. Ponadto jako biskup ubierał pończochy, buty, rękawiczki, pierścień, pektorał i mitrę, a w ręku trzyma pastorał ${ }^{20}$. Tym, co wyróżniało go spośród biskupów, była: falda, subcintorium, fanon, mantum oraz tiara.

Falda (nazywana również fimbria) to biała jedwabna spódnica nakładana papieżowi przez mistrza ceremonii jeszcze przed właściwym strojem liturgicznym. Charakteryzuje się zarówno dużą szerokością u dołu, jak i niezliczonymi fałdami. Po jej założeniu papież nie był w stanie iść sam, dlatego przepasywano ją podwójnym jedwabnym sznurem $\mathrm{z}$ bogatymi srebrnymi zdobieniami na końcu, a w czasie przejścia z przodu trzymało ją dwóch mistrzów ceremonii, a z tyłu dwóch papieskich szambelanów. „Zdaje się, że falda weszła w użycie za Juliusza II (†1513), papieża [...] Szerokość tej sukni ma przypominać bezgraniczną miłość namiestnika Chrystusowego dla wiernych"21. Możemy jednak przypuszczać, że powodem uprzednim do teologicznego była chęć podkreślenia majestatu i wielkości papieża oraz oddanie potęgi jego urzędu przez wielkość i bogactwo szat. Być może chciano w ten sposób „powiększyć” osobę Ojca św. (długa alba, szeroka spódnica, liczne szaty bogato zdobione), ukazać go potężniejszego i większego od uczestników wydarzenia? Wszak to, co widzimy, nie pozostaje bez znaczenia dla oceny całej sytuacji. Warto przypomnieć, że to właśnie za pontyfikatu Juliusza II, który wprowadził ten

dykta XVI, w: D. Brzeziński, M. Mikołajczak, J. Woźniak (red.), Benedykt XVI i liturgia, Płock 2018, s.123-141.

19 Szerzej na temat historii strojów liturgicznych pisał ks. prof. K. Konecki w artykule Pochodzenie i rozwój szat liturgicznych, „Anamnesis” 2 (1997/1998), s. 52-62.

${ }^{20}$ Zob. M. Mikołajczak, Teologiczna wymowa gestów i czynności celebransa, w Missale Romanum Piusa V i Mszale rzymskim dla diecezji polskich z 1986 r. (praca magisterska), Poznań 2013.

${ }^{21}$ A.J. Nowowiejski, Wykład liturgii Kościoła katolickiego, t. II, cz. I, Warszawa 1902, s. 459. 
strój, Państwo Kościelne najbardziej rozszerzyło swoje granice. Juliusz II il papa terribile, jak nazywano go w Rzymie

przyjął imię Juliusza, bo jego wzorem był starożytny Juliusz I: wszechwiedzący, wszystko pamiętający pogromca wszystkiego i wszystkich, boski Juliusz Cezar, zdobywca Europy i odnowiciel Rzymu, Roma triumphans, miasta, wokół którego kręci się świat. Juliusz II postanowił przywrócić, a nie tylko powierzchownie odnowić władzę polityczną Kościoła katolickiego ${ }^{22}$.

Ostatni raz uczestnicy solennej liturgii na Watykanie mogli zobaczyć ubranego w faldę św. Pawła VI. Żaden z Jego następców na piotrowym tronie nie założył tej części stroju papieskiego.

Alba nakładana na falde przewiązywana była najpierw subcintorium, a dopiero później właściwym cingulum. Subcintorium zwane inaczej subcingulum (dosłownie: pod cingulum / podpasek) była dodatkiem do papieskiego stroju - jedwabnym pasem koloru liturgicznego na którym, na jednym końcu wyhaftowany był złoty krzyż, a na drugim złoty baranek.

Uznani autorzy zauważają, że u początków (a więc XII i XIII w.) była to szata biskupia, a być może nawet kapłańska (co poświadcza Durand w swym Rationale divinorum officiorum) jednak już Caeremoniale episcoporum w ogóle o nim nie wspomina (pierwsze wydanie pochodzi z 1600 r.) - jej życie zachowane jest jednak w rycie ambrozjańskim (wg tzw. usus antiquor). Służyć ona miała podtrzymywaniu długiej w tamtym czasie stuły, którą poczęto skracać w Rzymie w XVI w. ${ }^{23}$

Błogosławiony abp Nowowiejski, przytaczając wypowiedzi św. Tomasza z Akwinu i Duranda, tłumaczy, że ta część stroju miała u swego początku zastosowanie czysto praktyczne: „podtrzymywanie i podnoszenie (subcingere) spadających pasów zbyt długiej wtedy stuły"24. W późniejszych czasach subcintorium utraciło pierwotne zastosowanie i nabrało wartości symbolicznej jako „znak gorliwości w szafowaniu jałmużny $\mathrm{w}$ najobszerniejszym tego słowa znaczeniu: jeden koniec tej szaty ma

22 R. Hughes, Rzym, Warszawa 2012, s. 214.

${ }_{23}$ B. Krzych, Historia, źródła i ceremonie solennej Mszy papieskiej, s. 195.

24 A.J. Nowowiejski, Wykład liturgii Kościoła katolickiego, s. 461. 
upominać noszącego ją do zmiłowania się nad duszą swoją przez unikanie grzechu, drugi zaś ma zachęcić do okazywania bliźniemu pomocy i miłosierdzia" 25 .

Papieski fanon (nazywany również orale) to rodzaj peleryny w kształcie koła o średnicy ok. $90 \mathrm{~cm}$, nakładanej przez głowę jako szatę wierzchnią. Wykonany jest $\mathrm{z}$ cienkiego jedwabnego białego materiału w złote pasy. Abp Nowowiejski wywodzi nazwę od gr. penos czyli chusta. Możemy jednak przypuszczać, że nazwa pochodzi od innego greckiego słowa, a mianowicie: fanos, co tłumaczymy jako: świecący, jasny, promienny, sławny. Formę fanon tłumaczymy jako blask ${ }^{26}$. Praktyka noszenia fanonu wywodzi się z XIII w., a wspomina o niej Durand i Innocenty III. Wykładnia alegoryczna przedstawiona przez papież Innocenty III tłumaczy noszenie fanonu jako naśladowanie arcykapłana Starego Zakonu, który zakładał na lnianą tunikę efod („Efod wykonają ze złotych nici i fioletowej i czerwonej purpury, karmazynu oraz kręconego bisioru, jako dzieło biegłych tkaczy..." - Wj 28,6). Fragmenty dotyczące ubioru kapłana żydowskiego w Księdze Wyjścia jasno ukazują, że ma się on wyróżniać spośród ludzi. Stroje liturgiczne wyróżniają kapłana od zebranych na liturgii ludzi, natomiast nałożony na papieskie ramiona fanon wyróżnia go w całym Kościele spośród kapłanów i biskupów. Biało-złota peleryna koncentruje wzrok uczestników liturgii na papieżu. Oglądając malowidła znajdujące się w egipskich piramidach, trudno nie odnieść wrażenia, że papieski fanon podobny jest do bogato zdobionych pektorałów nakładanych przez faraona.

Należy także zwrócić uwagę na papieskie mantum. Ten element stroju można było niejednokrotnie zaobserwować podczas liturgii sprawowanej przez Benedykta XVI, doświadczając jednocześnie wrażenia wielkości i potęgi. Wielkości i potęgi Następcy św. Piotra, dziś pierwszego wśród biskupów, niegdyś, gdy wprowadzano ten element stroju jako następcy Księcia Apostołów i potężnego władcy. O noszeniu „płaszcza” przez sprawującego liturgię dowiadujemy się już z Księgi Wyjścia $(28,4-5)$. Noszenie szerszego (większego) płaszcza - kapy przez papieża odnotowano w XI w. „Płaszcz papieski ma większe wymiary, co umoż-

25 Tamże.

${ }^{26}$ Zob. O. Jurewicz, Słownik grecko-polski, Warszawa 2000, s. 1034. 
liwiało objęcie nawet wielkiego tronu lub krzesła, gdy papież siedział na tronie lub był niesiony na sedia gestatoria. Jeśli papież chodził, krawędzie płaszcza, musiały podtrzymywać specjalnie wyznaczone osoby, zwane caudatori" ${ }^{27}$. Papież używał tego stroju, asystując od tronu podczas uroczyście sprawowanych liturgii, a także przed solennie sprawowaną przez siebie Mszą świętą w czasie procesji wejścia do Bazyliki św. Piotra oraz podczas konsystorzy. Mantum było koloru białego lub czerwonego bez względu na charakter sprawowanego oficjum. „Bł. Sikard z Kremony mówił, że szata ta oznacza świętą rozmowę, jej frędzle prace i troski ziemskiego życia, kaptur - przyszłą chwałę, zaś jej długość - wytrwałość, aż do końca"28.

Papieska tiara to potrójna złota korona, przypominająca kształtem ścięty ostrosłup na szczycie, którego znajduje się krzyż, a u dołu w tylnej części zwisają dwie taśmy (fanones). Zwyczaj noszenia nakrycia głowy podobnego do tiary (oraz biskupiej mitry) istniał już w Narodzie Wybranym. „I zrobisz też diadem ze szczerego złota i wyryjesz na nim, jak się ryje na pieczęci: „Poświęcony dla Pana”. I zwiążesz go sznurem z fioletowej purpury, tak żeby był na tiarze i żeby na przedniej stronie tiary był umieszczony" (Wj 28,36-37). W pierwotnym Kościele było to nakrycie głowy każdego biskupa. Biskupi na czele z papieżem nosili podczas sprawowania liturgii infuły (mitry) jako znak pasterstwa biskupiego (łac. mitra in signum Pontiffici). Z tego to nakrycia zrodziła się potrójna korona zwana tiarą - znak rządów świeckich (łac. regnum in signum Imperii ${ }^{29}$. Przyjmuje się, że pierwszym papieżem który ozdobił swój zawój (mitrę) złotą obręczą był Mikołaj I (†867), abp J.A. Nowowiejski twierdzi, że wydarzył się to o wiele wcześniej, nie wskazuje jednak, za którego pontyfikatu ${ }^{30}$. Następnie pojawiła się tiara z podwójną koroną. Według Viollet le Duc jako pierwszy nosił ją Bonifacy VIII (†1304) jednak sztuka tamtego czasu (grobowiec papieża, rzeźby, obrazy) tego nie potwierdzają. Tiarę z podwójną koroną możemy zauważyć dopiero

${ }^{27}$ M.C. Gallo, Vestire il Pontefice dall'Antico Testamento a Papa Francesco, Genova 2013, s. 65 (tłum. wł.).

${ }_{28}$ B. Krzych, Historia, źródła i ceremonie solennej Mszy papieskiej, s. 196.

29 Zob. F. Cancellieri, Descrizione de' tre pontificali che si celebrano nella Basilica Vaticana per le feste di Natale di Pasqua e di S. Pietro, Vaticano 1788, s. 90.

${ }^{30}$ Zob. A.J. Nowowiejski, Wykład Liturgii Kościoła Katolickiego, s. 464. 
na grobowcu Benedykta XII ( $\uparrow 1342)$. Bogato zdobiona tiara z potrójną koroną jako znak władzy świeckiej (regnum) weszła w użycie pod koniec XIII w.

Papież używał tiary „bardzo rzadko, bo tylko przy błogosławieństwach urbi et orbi, oraz podczas procesji papiezkiej do miejsca, gdzie się ma odbywać kaplica papiezka, nie zaś podczas samej mszy pontyfikalnej, w czasie której stoi ona na ołtarzu przed kandelabrami" ${ }^{31}$. Dalej abp. Nowowiejski pisze o znaczeniu teologicznym, które jest późniejsze do początkowego założenia towarzyszącego wprowadzeniu tiary w sposób następujący: „Potrójna jej korona uważana jest za symbol trojakiej najwyższej władzy (nauczycielstwa, kapłaństwa i rządzenia) jaką Chrystus król wszechświata, złożył na Biskupa Rzymskiego, oraz za symbol zjednoczenia trzech stopni hierarchicznych: biskupiego, patryalchalnego i papiezkiego, w jednej osobie Najwyższego kapłana" ${ }^{32}$.

Ostatnim koronowanym papieżem był św. Paweł VI. Jego następcy nigdy nie nosili tiary, jednak była ona nadal obecna w herbie papieskim - dopiero Benedykt XVI wymienił ją na biskupią mitrę.

Nakrycie głowy (zawój) wywodzi się z liturgii żydowskiej. Właściwym nakryciem głowy biskupa, a więc i papieża, jest mitra. Tiara z potrójną koroną pojawiła się bowiem na papieskiej głowie jako symbol władzy świeckiej, którą papież sprawował nad światem. Warto zwrócić uwagę na modlitwę, którą wypowiadał kardynał koronujący papieża:

Accipe tiaram tribus Coronis ornatam, et scias te esse patrem principum et regum, rectorem orbis in terra vicarium Salvatoris nostri Jesu Christi, cui est honor et gloria in saecula saeculorum ${ }^{33}$.

Zatem w ścisłym sensie tiara nie jest paramentum liturgicznym, a sensu stricto insygnium władzy papieskiej.

31 Tamże. s. 465.

32 Tamże, s. 465.

33 Przyjmij tę tiarę ozdobioną trzema koronami i wiedz, że tyś Ojcem książąt i królów, władcą świata, Wikariuszem naszego Zbawiciela Jezusa Chrystusa, którego jest cześć i chwała na wieki wieków (tłum. wł.). 


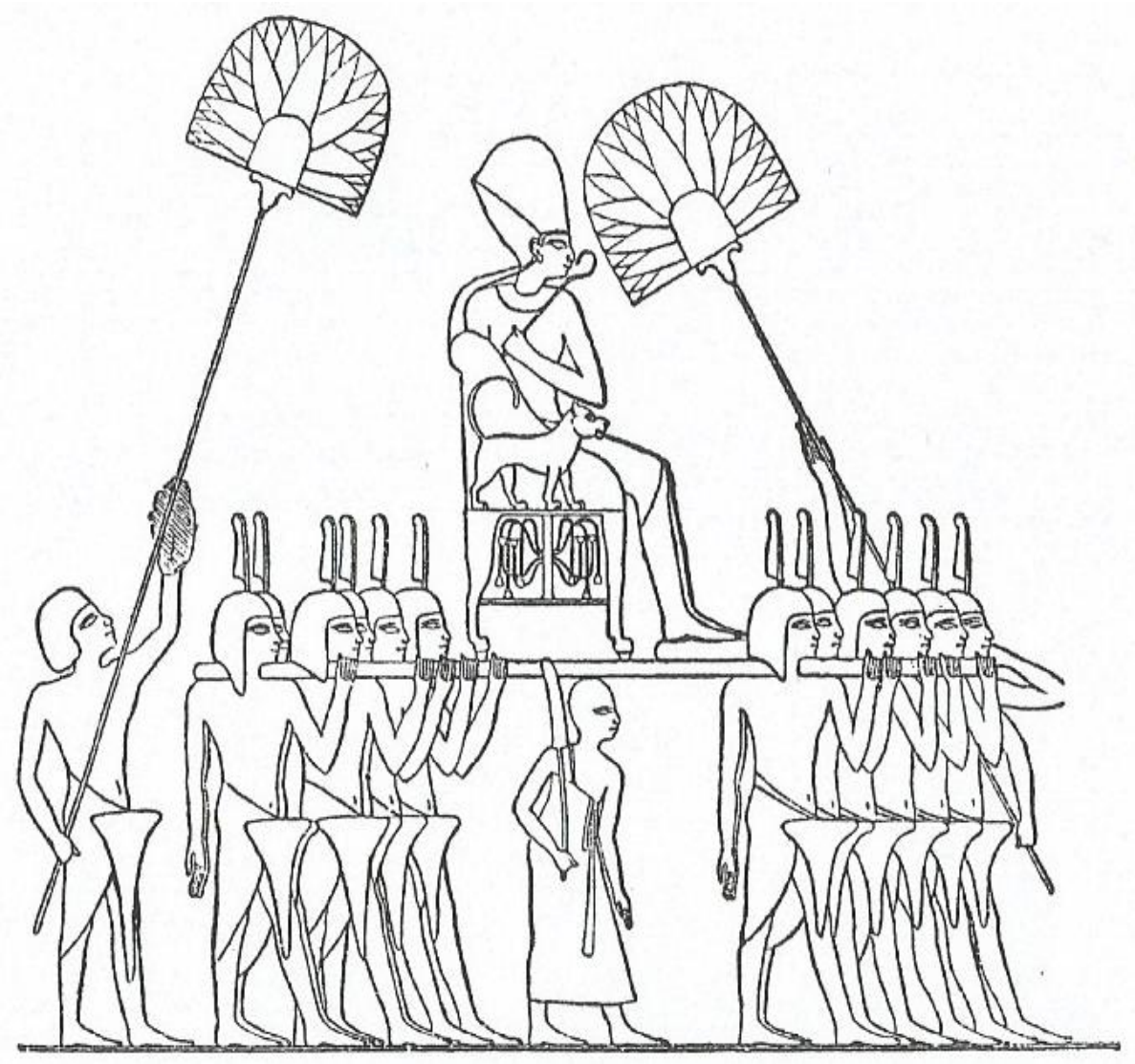

Ilustracja 1. Król Hareheb jest niesiony przez swoich żołnierzy podążających z przodu i tyłu i niosących pióropusze, obok niego, poniżej, znajduje się „niosący prawa króla”

\section{KTÓŻ MÓGŁBY POMYŚLEĆ O BARDZIEJ DONIOSŁEJ SYTUACJI?}

Najbardziej wzniosłym momentem było rozpoczęcie liturgii z udziałem papieża. Uroczysta procesja ukazywała potęgę i majestat następcy św. Piotra. Papież niesiony był do ołtarza na sedia gestatoria (lektyka) w pełnym, bogatym stroju, w otoczeniu dostojników zarówno kościelnych jak i świeckich, wśród dymu kadzideł i przy akompaniamencie

* Rysunek oraz opis: A. Erman, Aegypten und aegyptisches leben im Alterum, Tübingen 1923, s. 69 (tłum. wł.). 
podniosłej muzyki. Jak pisze abp. P. Marini, to wszystko nadawało papieżowi wygląd księcia tego świata. Uczestnik widział bogactwo, przepych i licznie zgromadzonych dostojników, czuł przyjemną woń kadzidła, słyszał uroczystą muzykę. Zaangażowanie zmysłu wzroku, węchu i słuchu nie było bez znaczenia. Uczestnik miał świadomość, że osoba centralna tego wydarzenia - papież, jest najważniejszy. Abp Nowowiejski opisuje rozpoczęcie papieskiej liturgii następująco:

Gdy papież niesiony jest $\mathrm{w}$ uroczystej procesji na sedia gestatoria, t. $\mathrm{j}$. na siedzeniu z drzewa pozłacanego pokrytem czerwonym aksamitem i obramowanem złotym galonem, dwaj tajni szambelani, idąc z boków, powiewają flabellami, już to dla wyrażenia dostojności Ojca chrześcijaństwa, już aby zwrócić jego uwagę pełnymi oczów piórami pawiemi, iż roztropnym być winien i na czyny swe baczyć, gdyż niezliczona liczba oczów ludu chrześcijańskiego wciąż nań patrzy ${ }^{34}$ (ilustracja 2).

Trudno nie zauważyć podobieństw do opisu procesji z udziałem faraona w starożytnym Egipcie. „Tak podąża pochód mijający widzów. Złocący się powóz, kolorowe pióropusze, kosztowne naczynia, kolorowe liście, białe powiewające szaty, to wszystko opromienia rozżarzone Słońce Egiptu - któż mógłby pomyśleć o bardziej doniosłej sytuacji?”35 (ilustracja 1).

W swoich analizach zjawiska procesji (uroczystego pochodu) D. Brzeziński wskazuje, że:

chociaż tak bardzo charakterystyczne dla liturgii chrześcijańskiej i dla chrześcijańskiej religijności ludowej - nie przynależy wyłącznie do chrześcijaństwa. Stanowi ono istotny element kultu spotykany we wszystkich znanych nam religiach, $\mathrm{i}$ - w pewnym sensie - zostało od nich przez chrześcijaństwo "przejęte” jako zewnętrzna forma religijności. Ponadto, również w tzw. laickiej sferze życia ludzkiego spotykamy wiele form zachowań społecznych: pochodów, orszaków i przemarszów, analogicznych do procesji religijnych ${ }^{36}$.

34 A.J. Nowowiejski, Wykład liturgii Kościoła katolickiego, s. 468.

35 A. Erman, Aegypten und aegyptisches leben im Alterum, s. 69.

${ }^{36}$ D. Brzeziński, Procesje w liturgii chrześcijańskiej. Geneza, teologia, duszpasterstwo, „Anamnesis” 48 (2007) 1, s. 62-71. 
Lektyka, mająca ukazać obserwatorom pochodu (procesji) osobę Ojca Świętego, wywodzi się z tradycji wschodu - przejęli ją Grecy, a następnie Rzymianie. Początkowo używano jej do transportu rannych i chorych. W późniejszych czasach służyła do transportu ludzi zamożnych oraz urzędników. Który z papieży jako pierwszy zasiadł na lektyce - nie wiadomo. „Przyjmuje się, że była ona w użytku Papieży około tysiąca lat"37. Historycy podają, że zwyczaj noszenia papieża (dawniej także biskupów, którzy byli wnoszeni do swojego katedry), sięga dawnych czasów i jest związany z tzw. Sedis Curulis - niesieniem nowo wybranego konsula przez miasto. Nad Następcą św. Piotra niesionym na tronie rozpostarty był bogato zdobiony baldachim podkreślający najwyższą godność w Kościele katolickim. Z lektyki zrezygnował św. Jan Paweł II w 1978 roku - w jej miejsce pojawił się papamobile. Pod koniec pontyfikatu zarówno Święty Papież, jak i Jego Następca Benedykt XVI korzystali z mobilnych platform umożliwiających pokonywanie większych odległości.

Uroczystemu wejściu towarzyszyła tzw. świta papieska. Sedia gestatoria niesiona była przez bussonanti (tzw. sediarze), w pobliżu nich szli dworzanie niosący papieskie berła. „Na czele najuroczystszych procesji dwóch lub trzech kapelanów papieskich niesie tiary (które potem umieszcza się przed kandelabrami ołtarzowymi po stronie Epistoły), co czyni się ad pompam - by dodać procesji splendoru godnego Biskupa Rzymu"38. W barwnym pochodzie uczestniczyła także Gwardia Szlachecka (wł. Nobile Guardia). Była ona jedną z trzech zbrojnych formacji papieskich obok: Honorowej Gwardii Pałacowej i Żandarmerii - również obecnych podczas uroczystości. Formacje zostały rozwiązane w 1970 roku przez papieża św. Pawła VI. Do dnia dzisiejszego w liturgicznej procesji towarzyszy papieżowi: Prefekt Domu Papieskiego wraz z najbliższymi współpracownikami papieża, oraz Mistrz Papieskich Ceremonii - wszyscy ubrani są w tzw. strój chórowy.

Dawniej w uroczystym pochodzie, asystujący papieżowi niesionemu na sedia gestatoria, dwaj tajni szambelani powiewali po bokach okazałymi wachlarzami. Flabellum, o długiej rękojeści, początkowo używany był w liturgii do odganiania much i chłodzenia, co potwierdza napis na

\footnotetext{
37 B. Krzych, Historia, źródła i ceremonie solennej Mszy papieskiej, s. 198.

38 Tamże, s. 196.
} 
jednym z nich z XI w. ${ }^{39}$ Nie miało ono jednak tylko zastosowania praktycznego, niesione przy Ojcu Świętym miało również za zadanie podkreślić dostojeństwo urzędu Piotrowego. Abp A.J. Nowowiejski w swoim dziele, również podkreśla podobieństwa do dworu faraona. „Znała go cała starożytność. Wzmiankują o nim Mahābhārata i Rāmāyan. Obok baldachimu służył od czasów najdawniejszych za godło potęgi królewskiej. W Egipcie sam jeden faraon miał prawo go używać; urzędnik, noszący flabellum $\mathrm{z}$ lewej strony tronu, zaliczał się do rzędu wysokich dygnitarzy" ${ }^{40}$. Wykonane z pawich piór (charakterystyczne pawie oczy) miały przypominać papieżowi, że oczy całego ludu chrześcijańskiego zwrócone są właśnie na niego. „Dodać należy, że drzewce tego wachlarza są obszyte czerwonym aksamitem oraz zakończone półkolem, na którego tle znajdują się klucze świętego Piotra, a z którego to półkola wychodzą dwa rzędy strusich piór wymieszanych z piórami pawimi”" ${ }^{41}$.

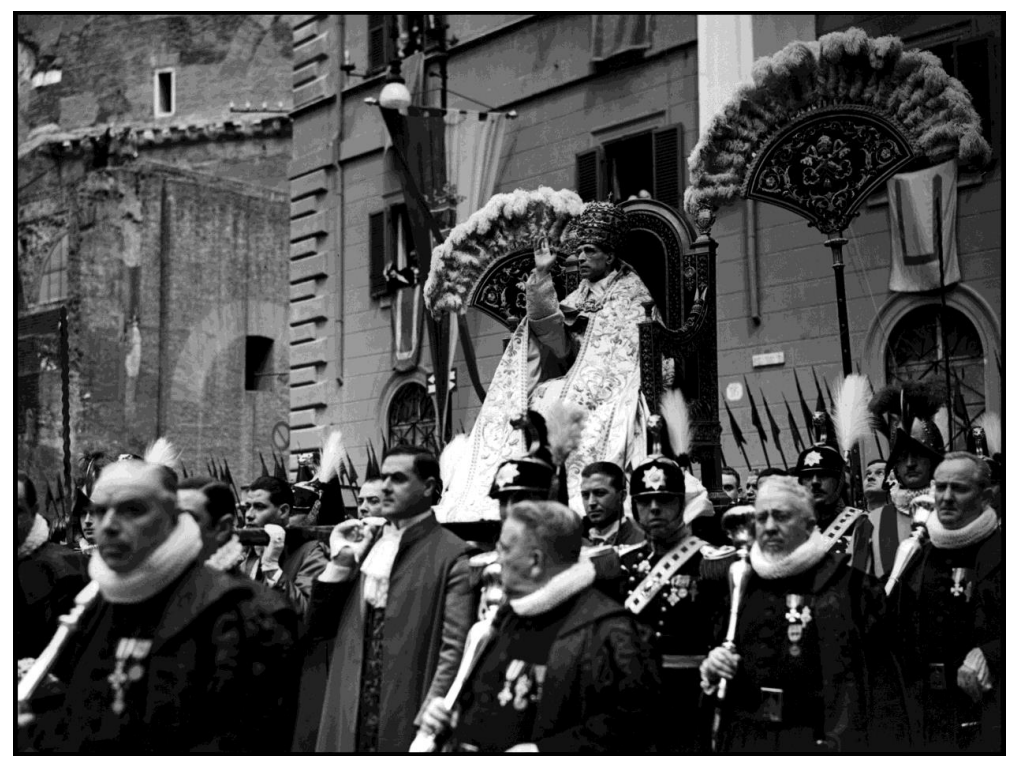

Ilustracja 2. Pius XII niesiony w uroczystym pochodzie, rok 1940 (@ MP/Portfolio/ Leemage)

39 Zob. A.J. Nowowiejski, Wykład liturgii Kościoła katolickiego, s. 467.

40 Tamże. s. 466.

${ }^{41}$ B. Krzych, Historia, źródła i ceremonie solennej Mszy papieskiej, s. 199. 


\section{SŁUGA SŁUG BOŻYCH}

Potrzeba większej przejrzystości liturgii papieskiej i ukazania tego co w niej najważniejsze stała się przyczyną podjętych reform. Mistrz papieskich ceremonii zwraca uwagę przede wszystkim na problem odbioru papieskiej liturgii przez osoby nieznające rzymskich tradycji czy osoby niewierzące, które mogą uczestniczyć w liturgii (dzięki rozwijającej się komunikacji jest to bardziej dostępne) lub ją obserwować dzięki transmisjom telewizyjnym. W swoich wspomnieniach zanotował:

Odczuwano konieczność zrewidowania zespołu osób stojących obok papieża (kardynałowie, biskupi, i inni duchowni, którzy pełnili drugorzędne posługi), aby uczynić bardziej przejrzystą prawdę o pełnionej posłudze każdej z nich. Ponadto odwołano się do psychologii współczesnego człowieka, który nie rozumie pomieszania pomiędzy etykietą dworską a religijnym rytuałem i zaproponowano zniesienie tej swego rodzaju świty, która otaczała papieża podczas celebracji liturgicznych. [...] Niektóre średniowieczne praktyki, wyniesione poza rzymskie otoczenie do ludzi innych wyznań lub do niewierzących, powodują rozmaite i nie zawsze pozytywne interpretacje. Papież musiał ukazać się wszystkim jako Następca Piotra, Sługa Sług Bożych, a nie jako średniowieczny książę. [...] Szaty liturgiczne wymagały uproszczenia dla uniknięcia sytuacji, kiedy niektórzy duchowni wyglądali jak „teatralni statyści” ${ }^{42}$.

Oczyszczając liturgię papieską, Watykan zrezygnował z dworskiej etykiety wplatanej w celebrację. Papieska liturgia ponownie staje się czystym kultem składanym Bogu, a nie manifestacją potęgi papiestwa.

W niniejszym przedłożeniu skupiliśmy się na wpływach świeckiego ceremoniału na liturgię papieską. Stanowi to początek do dalszych poszukiwań, a także zwrócenia uwagi na „liturgiczne korzenie” ${ }^{43} \mathrm{w}$ ceremoniałach świeckich. Wszak jak zanotował Ernest Kantorowicz:

${ }^{42}$ P. Marini, Liturgia i piękno. Nobilis pulchritudo, s. 74-75.

${ }_{43}$ Zob. M. Lorenc, M. Mikołajczak, Liturgical references in the swearing-in ceremonies of the President of the Republic of Poland after 1989, „Srodkowoeuropejskie studia polityczne" 3/2018, s. 135-156. 
Papież ozdobił tiarę złotą koroną, przywdział cesarską purpurę, a gdy objeżdżał w uroczystej procesji ulice Rzymu niesiono przed nim cesarskie flagi. Cesarz zakładał pod swą koronę infułę, przywdziewał pontyfikalne sandały i inne szaty duchownych, a podczas koronacji, podobnie jak biskup, otrzymywał pierścień ${ }^{44}$.

\section{BIBLIOGRAFIA}

Brzeziński D., Procesje w liturgii chrześcijańskiej. Geneza, teologia, duszpasterstwo, „Anamnesis" 48 (2007) 1, s. 62-71.

Cancellieri F., Descrizione de' tre pontificali che si celebrano nella Basilica Vaticana per le feste di Natale di Pasqua e di S. Pietro, Vaticano 1788

Cataldi Gallo M., Vestire il Pontefice dall, Antico Testamento a Papa Francesco, Genova 2013.

Erman A., Aegypten und aegyptisches leben im Alterum, Tübingen 1923.

Heintze M., Symphonia, simphoniacus u Petroniusza - analiza semantyczna, w: Symbolae Philologorum Posnaniensium Graecae et Latinae XXIX (2019) 1, s. 53-63.

Hughes R., Rzym, Warszawa 2012

Janicki J., Kultury antyczne w liturgii chrześcijańskiej, Kraków 2007.

Jurewicz O., Słownik grecko-polski, Warszawa 2015.

Kantorowicz E., Dwa ciała króla: studium ze średniowiecznej teologii politycznej, Warszawa 2007.

Kępczyński M., Strój liturgiczny i pozaliturgiczny w papieskiej praxis Benedykta XVI, w: D. Brzeziński, M. Mikołajczak, J. Woźniak (red.), Benedykt XVI i liturgia, Płock 2018, s. 123-141.

Konecki K., Pochodzenie i rozwój szat liturgicznych, „Anamnesis” 2 (1997/1998), s. 52-62.

Krzych B., Historia, źródła i ceremonie solennej Mszy papieskiej wedlug usus antiquior, „Christianitas” 52 (2013), s. 178-179.

Landels, J.G., Muzyka starożytnej Grecji i Rzymu, Kraków 2005.

Liber usualis. Missae et officii, Parisiis-Tornaci-Romae 1951.

Lorenc M., Mikołajczak M, Liturgical references in the swearing-in ceremonies of the President of the Republic of Poland after 1989, „Środkowoeuropejskie Studia Polityczne" 3 (2018), s. 135-156.

Marini P., Liturgia i piękno. Nobilis pulchritudo, Pelplin 2007.

Mikołajczak M., Teologiczna wymowa gestów i czynności celebransa w Missale Romanum Piusa V i Mszale rzymskim dla diecezji polskich z 1986 r. (praca magisterska), Poznań 2013.

${ }^{44}$ E. Kantorowicz, Dwa ciała króla: studium ze średniowiecznej teologii politycznej, Warszawa 2007, s. 157. 
Nadolski B., Liturgika, t. I: Liturgika fundamentalna, Poznań 1989.

Nowowiejski A.J., Wykład liturgii Kościoła katolickiego II, Warszawa 1902.

Olejarz T., Podmiotowość Stolicy Apostolskiej w prawie międzynarodowym, „Annales Universitatis Mariae Curie-Skłodowska" vol. XVI (2009) 1, s. 65-94.

Orłowski T., Protokół dyplomatyczny. Między tradycją a nowoczesnością, https://wszystkoconajwazniejsze.pl/tomasz-orlowski-protokol-dyplomatyczny/ (dostęp: 25.05.2020).

Plezia M. (red.), Słownik łacińsko-polski, Warszawa 2007.

Sobór Watykański II, Konstytucja o liturgii świętej „Sacrosanctum Concilium”, w: tenże, Konstytucje, dekrety, deklaracje, Poznań 2002, wyd. II, s. 48-78.

Sobór Watykański II, Konstytucje, dekrety, deklaracje, Poznań 2002.

Suchocka H., W 75 rocznice podpisania Traktatów Laterańskich. Refleksje na temat relacji Stolica Apostolska a Państw-Miasto Watykan, w: A. Dębiński, K. Orzeszyna, M. Sitarz (red.), Ecclesia et Status. Ksiega jubileuszowa z okazji 40-lecia pracy naukowej ks. profesora Józefa Krukowskiego, Lublin 2004. 